\title{
BIRDCATCHING IN SURINAM
}

BY

THOMAS E. PENARD and ARTHUR P. PENARD

\section{With 14 illustrations}

In Surinam birds are trapped for three distinct purposes - (1) for the table; (2) for the cage; or (3) because they are said to be troublesome in field or garden.

The first group contains primarily the Quails (Odontophoridae), Pigeons and Doves (Columbidae), Rails (Rallidae), rarely the Ducks (Anatidae), and sometimes the larger passerine birds.

The second group includes the Macaws, Parrots, and Paroquets (Psittacidae), Thrushes (Turdidae), Seedeaters (Fringillidae), Tanagers (Tanagridae), Orioles and Blackbirds (Icteridae), and Jays (Corvidae).

In the third group are the Seed-eaters, and the Grackles and Blackbirds, particularly the following species:

Molothrus bonariensis minimus (Dalmas). Cowbird. "Ningre-sipi" (Negro-ship), or "Pikien Karoe-fowroe" (Little Corn-bird) ${ }^{1}$ ).

Agelaius icterocephalus icterocephalus (Linn.). Yellowheaded Reed-bird. "Geel-hede Karoe-fowroe" (Yellowheaded Corn-bird).

Cassidix oryzivora oryzivora (Gmelin). Rice Grackle. "Bigi Karoe-fowroe" (Big Corn-bird).

Holoquiscalus lugubris lugubris (Swainson). Swainson's Grackle. "Geel-ai Karoe-fowroe" (Yellow-eyed Cornbird), or Tjapoe-tiki (Ax-handle).

1) Native names and expressions in Negro-English are written in accordance with Dutch phonetics, following more or less closely the spelling in H. C. Focke's Neger-Engelsch Woordenboek, Leiden, 1855. 
In general the Surinam birdcatcher employs the following means and methods: (1) a fall-trap or "kravanna"; (2) a trap-cage or "knipkooi"; (3) birdlime; (4) snares; and (5) nest robbing.

\section{THE KRAVANNA}

The "kravanna" is a coop trap made of twigs and sticks, graded in length and arranged in square pyramidal form with the longest pieces at the base. The whole structure is drawn together and held firmly by two strings, or tough bush-ropes, fastened at the four corners and twisted together at the top by means of a little stick around which the strings are looped. The contrivance very much resembles the coop trap used in some parts of the United States ${ }^{\mathbf{1}}$ ) and in Bermuda ${ }^{2}$ ).

Any kind of wood may be used in making the trap, but it is best to use rustic material. A good wood, generally favored for this purpose, is the "Bralief" or "Bradi-lifi (Broad-leaf), Coccalobia latifolia Lam., which grows abundantly in the pastures about Paramaribo. The trunk is straight and is easily split to suit.

To set the trap one edge is raised from the ground and supported by means of a light prop made in two parts and halved to fit. Through the joint a string is looped and fastened to the opposite corners of the trap, carefully adjusted so that it will be an inch or so above the ground. Bait is scattered in front of the kravanna in such a manner as to lead to and under the trap where a more tempting quantity is placed. The nature of the bait depends, of course, upon the species desired. Thus for finches and blackbirds rice is used, and for pigeons corn or lime seeds. In attempting to reach the bait the bird stumbles over the string, the prop collapses, and the trap falls.

A kravanna for seed-eaters (Sporophila sp.) must be of

1) There is an illustration of such a trap in W. H. Gibson's Camp Life in the Woods and the Tricks of Trapping and Trap Making, 1902, p. 68. This differs somewhat in details of construction, but in principle it is the same as the kravanna.

2) Cf. John Matthew Jones, The Naturalist in Bermuda, 1859, p. 64. 
much lighter construction than one for pigeons or quails, otherwise it will fail to trip. Sometimes the birdcatcher operates the trap himself from a suitable hidingplace, by means of a string fastened to the prop. A simple form of fall-trap consists of a board supported by a prop at one end and placed over a depression in the ground.

The following species, among others, are caught in kravannas:

Eupsychortyx sonnini sonnini (Temminck). Sonnini's Crested Quail. "Sabana Patrijs" (Savanna Partridge), or "Anamoen".

Chaemepelia passerina griseola (Spix). Spix's Gray Ground Dove. "Pikien Pinni-hatti Ston-doivi" (Little Speckled-breast Stone-dove).

Chaemepelia talpacoti (Temminck). Talpacoti's Ground Dove. "Redi Ston-doivi" (Red Stone-dove).

Chaemepelia arthuri Bangs and Penard. Arthur's Ground Dove. "Redi Ston-doivi" (Red Stone-dove).

Leptotila rufaxilla rufaxilla (Rich. and Bern.). Grayfronted Dove. "Passi Doivi" (Path Dove).

Pardirallus maculatus (Boddaert). Spotted Rail. "Blakka-nanga-witti Anamoen" (Black and White "Anamoen”) or "Toke Anamoen" (Guinea Hen “Anamoen”).

Aramides cajanea cajanea (Müller). Cayenne Rail. "Kriko" (in imitation of its call), or "Bigi Kriko" (Big Kriko).

Porzana albicollis (Vieillot). White-necked Crake. "Greisi Anamoen" (Gray “Anamoen”), or "Potlood Anamoen” (Lead Pencil “Anamoen”).

Ramphocelus carbo carbo (Pallas). Velvet Tanager. "Witti-mofo Kieng" (White-mouthed "Kieng"), male; or "Redi Kieng” (Red “Kieng”), female.

The Tinamous (Tinamidae) are rarely, if ever, victims of the kravanna. This fact is so well known that it has given rise to a local proverb: "Fowroe joe sa kisi nanga karoe, ma Anamoe joe no kan kisi" (Fowl you will catch with corn, but Tinamou you cannot catch). 


\section{THE KNIPKOOI}

The "knipkooi", also called "klepkooi", is a trap-cage with three compartments - a lower intended for the decoy, and two upper which are the traps. Occasionally an ambitious trapper makes one with four or more traps, but such cages are exceptional, and certainly not any more effective than the double-trap device. The two perches in the lower compartment are known as "djompotiki" (jump-sticks), and the suspension hook as "akkasetti-tiki" (hook-set-stick). The wood used in making these cages is preferably Cedar, Cedrela odorata L., but "Pisi" (Nectandra sp.) and other native wood are also used. For the wires "prientas" are used. The "prienta" is the midrib of the leaflet of certain palms, particularly the Cokerite, Maximiliana maripa Drude.

The double-trap cage is comparatively small. For Finsch's Euphonia Tanagra finschi (Sclater and Salvin), the dimensions are approximately: length, $20 \mathrm{~cm}$.; width, $8 \mathrm{~cm}$.; height, $19 \mathrm{~cm}$. For the Violet Euphonia, Tanagra violacea violacea (Linn.), the cage is a little larger. The trap itself is a very ingenious device. The door, called the "klep", is at the top, and consists of three parallel strips of wood connected across by "prientas" which pass through them, the middle strip being the longest and extending back beyond the other two. The door is hinged by means of two strings twisted together known as "span-tetei" (tension-string). These straddle the middle strip and pass through corresponding holes in the side strips and the frame of the cage, where they loop around a small piece of wood on each side. By twisting the string tension is produced to close the door swiftly when released.

When the trap is set the door is held in position by means of a notched perch which engages the long middle strip and presses against the partition between the two trap compartments ${ }^{\mathbf{1}}$ ). The bait is placed directly under

1) Gibson (loc. cit., p. 76) shows a trap cage in which a similar principle is applied. 
the perch. When the bird hops in to get at the food the perch slips down and releases the door which closes instantly. It may be necessary to fasten a weight to the door or to provide a latch so that the struggling captive cannot force its way out. Usually, however, the tension of the twisted string is sufficient to prevent this. Taking advantage of the pugnacity of the Euphonias, the birdcatcher sometimes puts a small mirror in the trap. The cage, with both traps adjusted, is hoisted into a tree by means of a strong cord thrown over a branch, the other end of the cord being fastened to the bottom of the cage to guide the latter while it is being pulled up or down. That portion of the line which passes over the branch is known as the "hesi-tetei" (hoisting cord) and the end hanging down from the bottom of the cage, the "stuur-tetei" (steering cord) or "kamisa"-tetei" (breech-cloth cord). Captured birds are temporarily confined in a small cage without traps, known as "kweek-kooi" (stock cage).

The trap-cage is employed in catching all kinds of small birds, but particularly the Euphonias (Tanagra sp.) of which we shall speak more fully later. The following species are also caught:

Tangara cayana cayana (Linn.). Cayenne Tanager. "Goudvink" (Goldfinch), or "Gewone Vink" (Common Finch).

Tangara mexicana mexicana (Linn.). Sulphur-bellied Tanager. "Portretvink" (Portrait Finch), or "Epauletvink" (Epaulet Finch).

Thraupis episcopus episcopus (Linn.). Blue Bishop. "Blauwfortji" (Bluebird), or "Sapatija Blauwfortji" (Sapodilla Bluebird).

Thraupis palmarum melanoptera (Sclater). Palm Tanager. "Kokronoto Blauwfortji" (Cocoanut Bluebird).

Ramphocelus carbo carbo (Pallas). Velvet Tanager. "Witti-mofo Kieng" (White-mouthed "Kieng), male; or "Redi Kieng” (Red “kieng”), female.

Tachyphonus rufus (Boddaert). Black Tanager. "Blakka Kieng" (Black "Kieng”). 
Nemosia pileata pileata (Boddaert). Hooded Tanager. "Geel-ai Vink" (Yellow-eyed Finch).

Hemithraupis guira nigrigula (Boddaert). Black-throated Olive Tanager. "Mangro-kanari" (Mangrove Canary).

Turdus nudigenis Lafresnaye. Bare-eyed Thrush.

"Geel-ai Boontjedief" (Yellow-eyed Bean Thief).

Turdus albiventer albiventer Spix. White-bellied Thrush. "Bruin-flei Boontjedief" (Brown-winged Bean Thief).

Many species of small insectivorous birds, undesirable from the birdcatcher's point of view, attracted by the insects on the bait, are from time to time caught.

Bird cages hung in trees are always in danger of attack by birds of prey. The common Great-billed Hawk, or "Doivi Akka" (Pigeon Hawk), Rupornis magnirostris magnirostris (Gmelin), is a great offender in this respect. It has been known to destroy cage pets even in the gardens in the city. Toucans and woodpeckers occasionally break the cages in trying to get at the bait or the insects on it. Wasps are also troublesome, and have been known to sting the decoy, 'particularly a black wasp known as "Kapasi Wasi-wasi" and a red one called "Fransman Wasi-wasi", both larger than the common house wasp. Snakes, too, are reported as having entered the cages.

BIRDLIME

Birdlime, known in Surinam as "tara" (tar), is an important factor in bird trapping and is used either with or without the trap-cage. Among the trees or vines that furnish the sap from which the birdlime is made, are the following:

1. "Bredebom" (Beadfruit), Artocarpus sp.

2. "Koeli Bredebom" (Coolie Breadfruit).

3. "Gum".

4. "Melki-tetei" (Milk-rope), Mandevilla sp.?

The preparation of the birdlime is very simple. The trunk of the tree is slashed and the sap allowed to accumulate for about an hour. The watery portion is not col'ected. The sap is used either raw or boiled. Its proper- 
ties depend upon the species of plant from which the sap has been taken. For example, lime made from the sap of the "Gum" tree is very tough and may cause injury to the bird, while that made from the sap of the breadfruit, "bredebom melki", is rather soft and may not have sufficient strength to hold the bird. With these facts in mind, the birdcatcher goes to work and makes a mixture of the two to obtain the desired consistency. The addition of vinegar, lime juice, or tallow, when boiling, imparts to the birdlime certain properties. Some boys chew the viscous mass, believing that its quality is thereby improved.

Birdlime made from the "Melki-tetei" is excellent. This liane grows in the forests in the vicinity of Paramaribo. It is impossible to pull these bush-ropes down from their moorings in the forest roof, so the trapper simply takes what he can reach from the ground or by easy climbing. This he cuts up into smaller pieces and scrapes off the sap that oozes out at the ends.

Some birdcatchers cultivate the "Gum" tree and Breadfruit in their fields or gardens. An old Breadfruit tree with its trunk scarred almost beyond recognition by countless cuts and slashes, received during many years of its useful life, is truly a pathetic sight.

In applying the birdlime it is carefully wound, not smeared, on a twig or stick, or an umbrella rib. First, however, the birdcatcher takes the precaution to moisten the stick so that he may afterwards remove the sticky substance more easily. For the same reason he also wets his fingers while handling the "tara". The umbrella rib is much in favor, because the birdlime can be more easily removed from it without loss than from the wood. The stick covered with birdlime is called a "tara-tiki" (tarred stick). Usually it is from 30 to $40 \mathrm{~cm}$. long, the thickness depending upon the species the birdcatcher is after. For the Euphonias and small seed-eaters the umbrella rib is just right. When not in use the "tara" is put in a bottle of water, where it will keep a short time without spoiling, care being taken to change the water from time to time. 
But after a while it becomes stringy and loses much of its tenacity. When in that condition it is said that "a kisi anansi tetei" (it has the cobwebs).

When the "tara-tiki", instead of being attached to the cage containing the decoy, is placed at some distance from it, the method is known as "valsch-tara" (false tar). If fastened to an empty cage it is also called "valschtara", and the same name serves when the birdlime is applied directly to a twig, bush, or tree, stalk of grass, branch of berries or fruit, hung near the cage. Sometimes the lime is smeared on the edge of a bird's nest. A simple method, employed by little boys, is to attach the "taratiki" to a bunch of bananas, where they are sure to catch a number of species, particularly the "Baana-bekki" (Banana-bill), Cacicus cela (Linn.).

Birdlime is used for tanagers, seed-eaters, and paroquets, but many other species such as wrens, flycatchers, and even hummingbirds are unintentionally caught, much to the disgust of the birdcatcher. Not infrequently insects, drawn by the odor, entangle themselves in the birdlime, spoiling it beyond recovery.

\section{SNARES}

Snares made of horse hair are now rarely employed by birdcatchers in Surinam. When used they are laid upon the plants frequented by the birds in search of food.

We have been informed of a curious device made of sticks arranged crosswise to form a latticed platform, on which the snares are placed. This contraption is mounted on a pole in a prominent position, offering an attractive perch. We understand that it was formerly used at Fort Amsterdam to catch the Redbreasts, Leistes militaris militaris (Linn.), which are still abundant in the fields there.

\section{NEST ROBBING}

Nestlings of any species, when accidentally found, may, of course, be taken, but no deliberate hunt is made for them except in the case of macaws, parrots, and paroquets. 


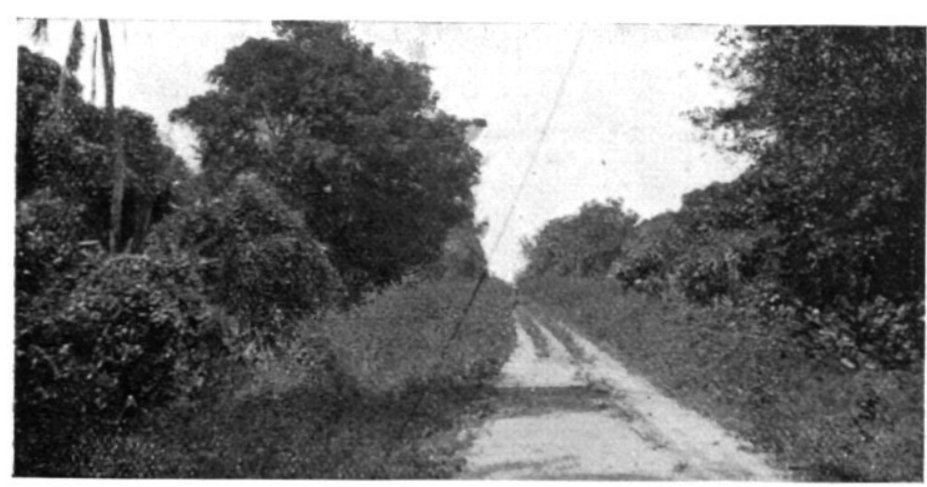

1. The road to Krepi

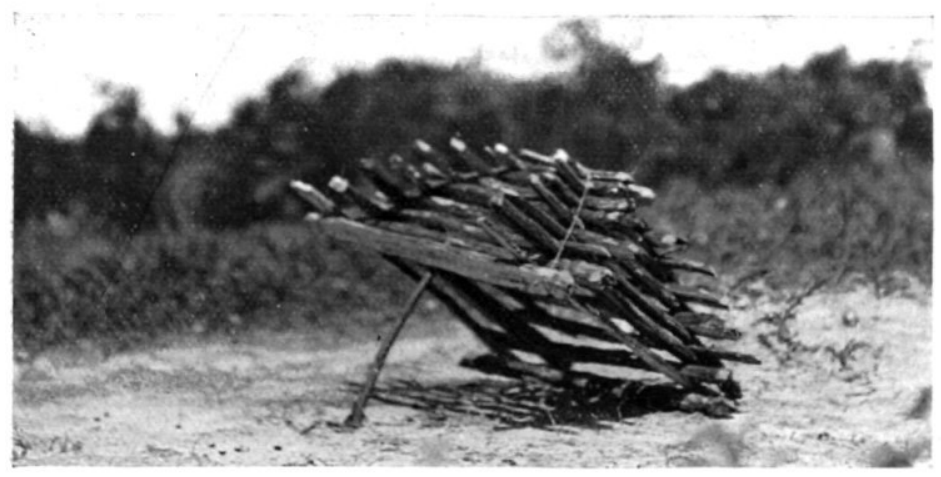

2. Kravanna set in watermelon patch

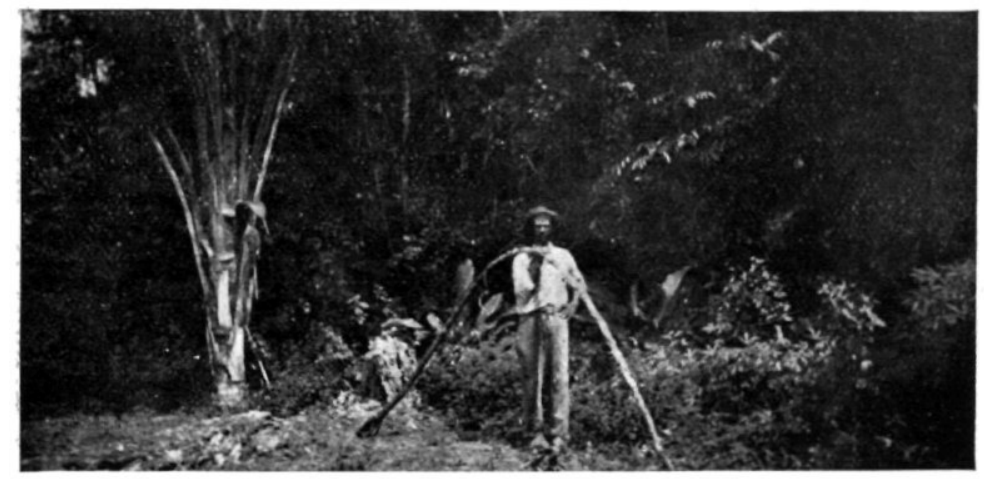

3. Trapper coming out of the woods with a piece of "melki-tetei" 


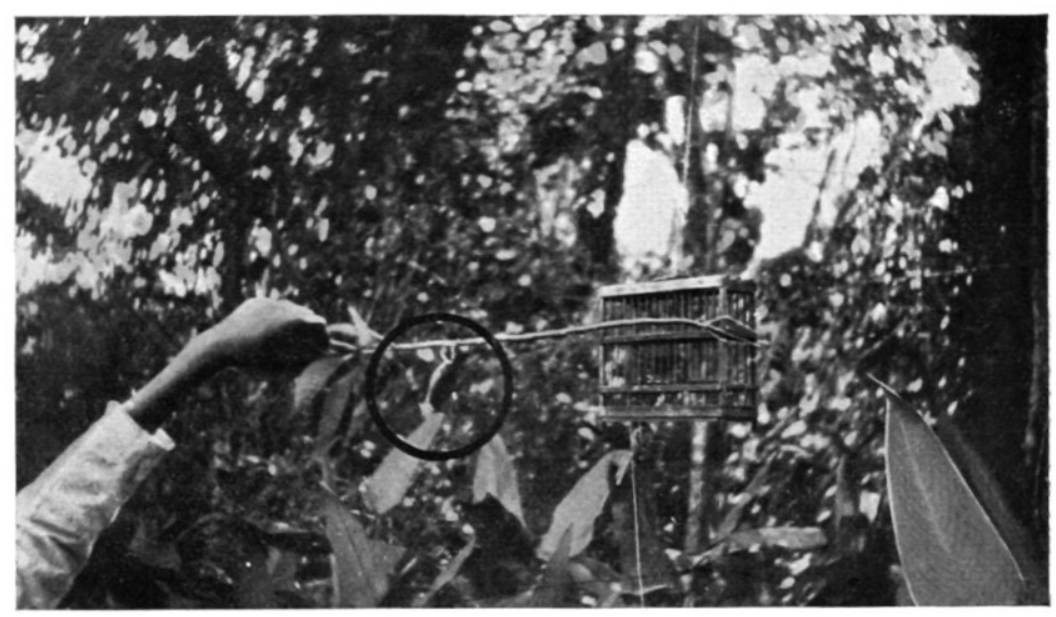

4. Trap-cage with Yellowthroat caught on birdlime

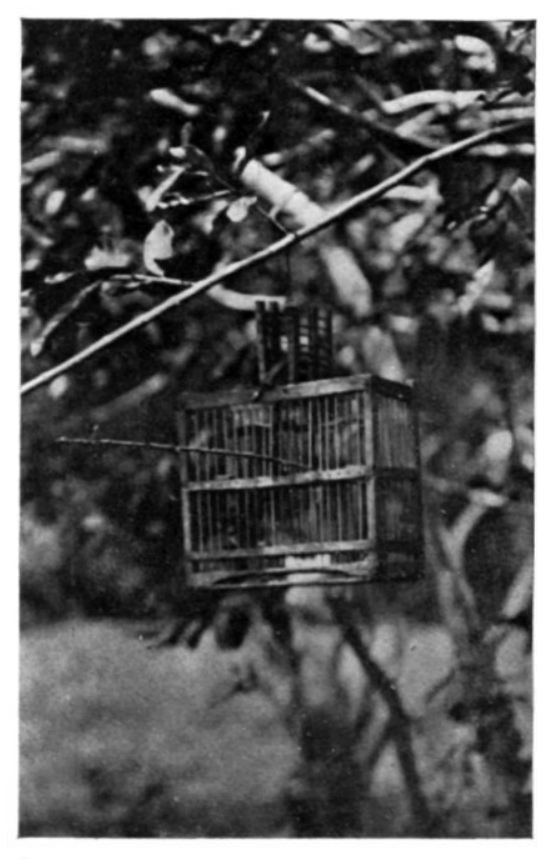

5. Trap-cage with traps set and "tara-tiki"

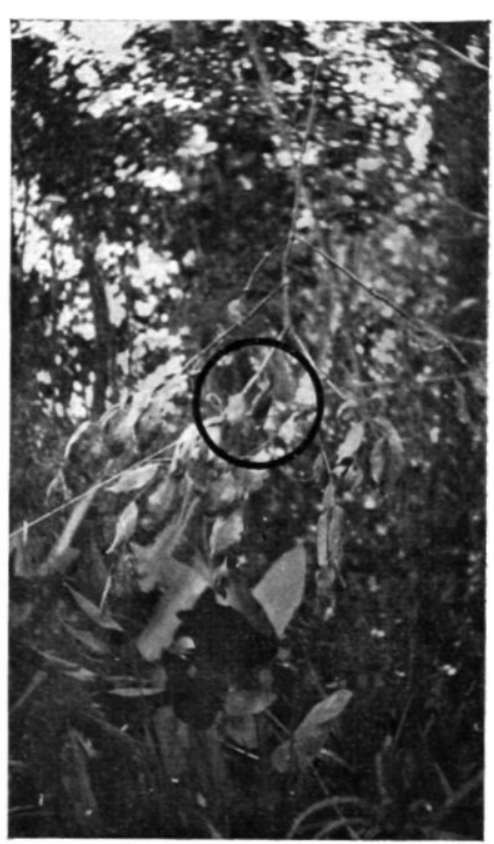

6. "Seed-branch" with Yellowthroat caught on birdlime 


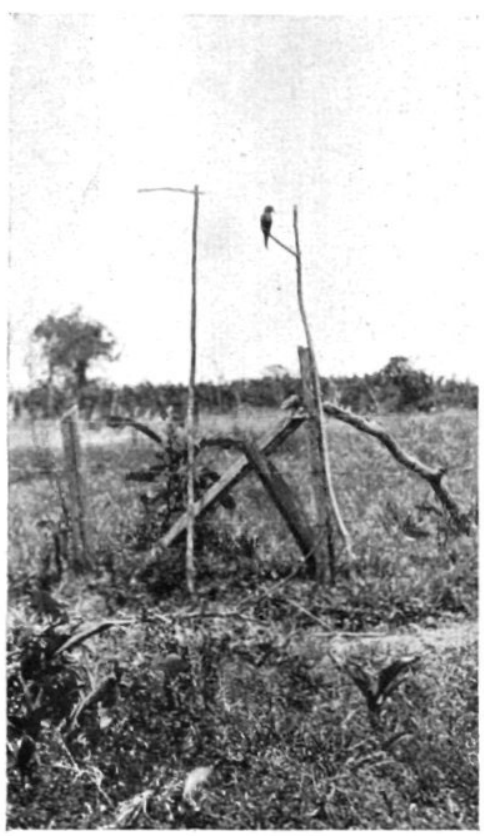

7. Brown-throated Paroquet set, "valsch-tara" method

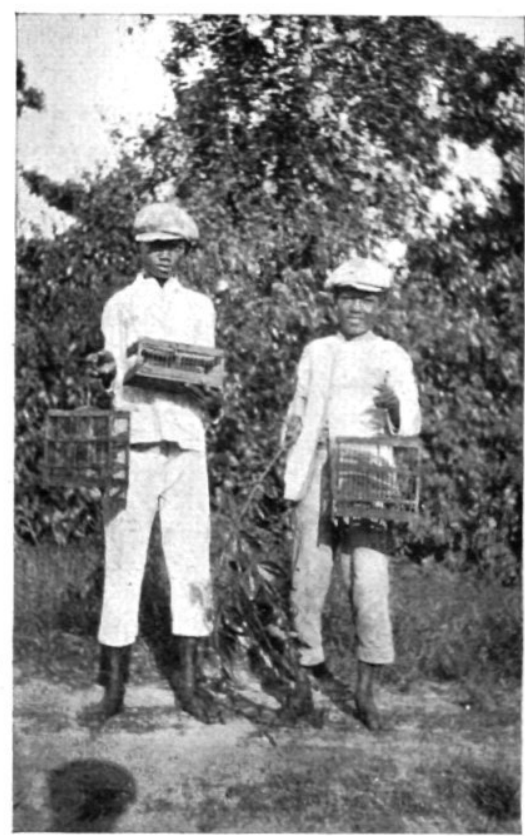

9. Birdcatchers with trap-cages, stock cage, and " seed-branch" with birdlime

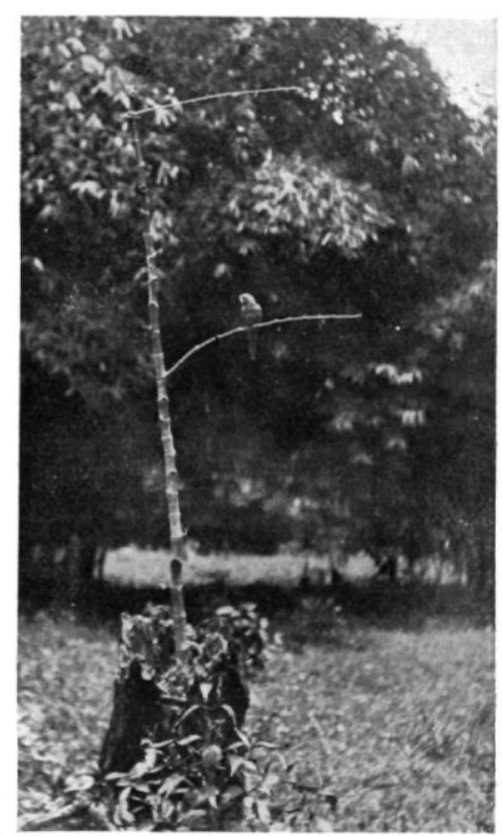

8. Brown-throated Paroquet set, with "tara-tiki" overhead

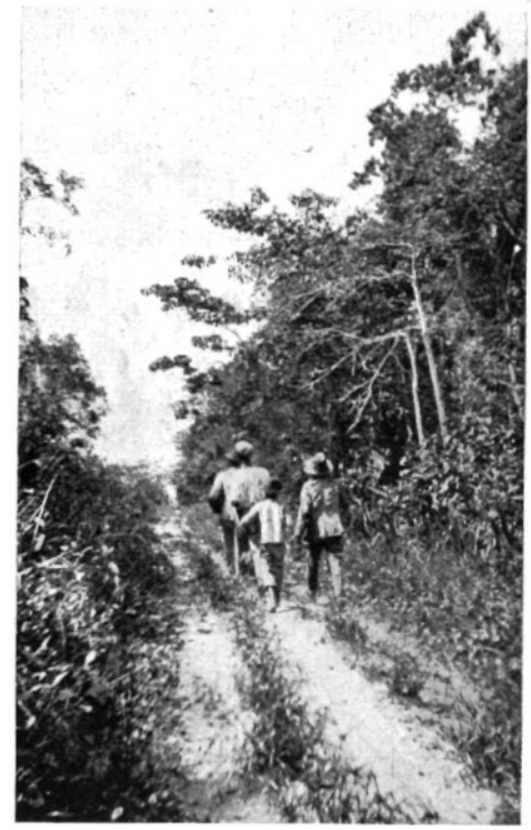

10. Birdcatchers on their way to the hunting grounds 


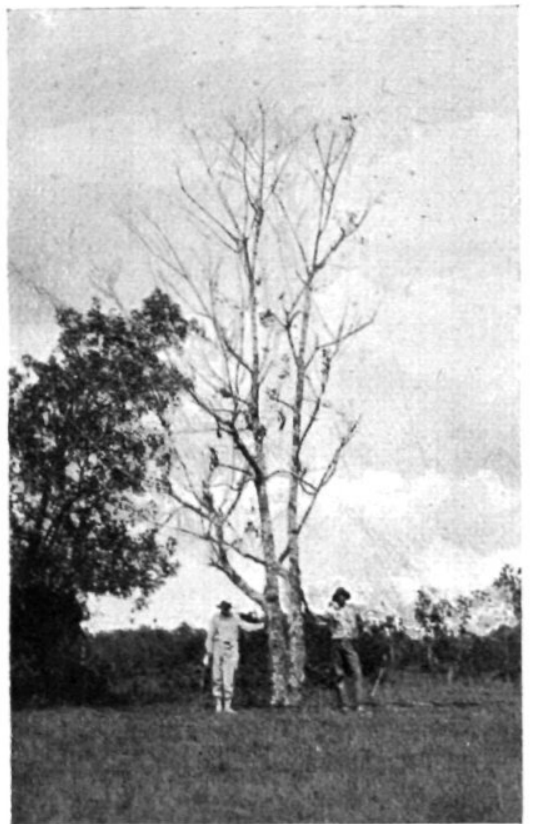

11. The "gum" tree

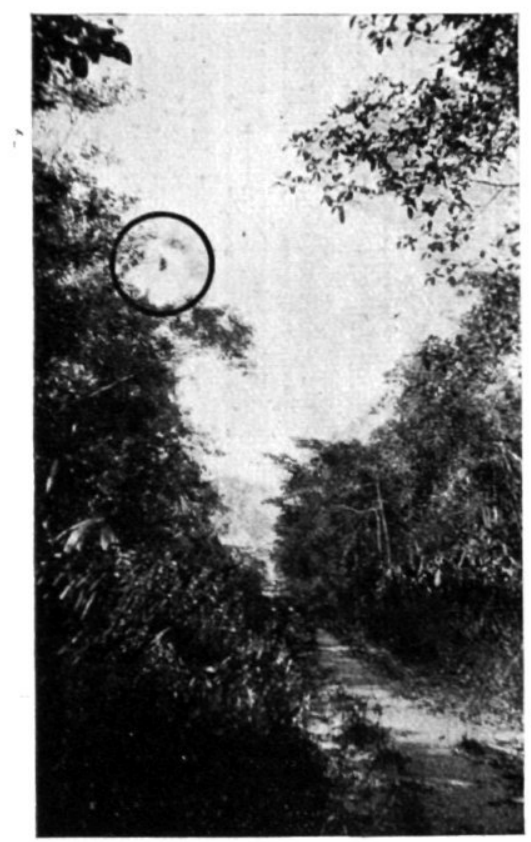

13. Trap-cage hung at side of road at Krepi

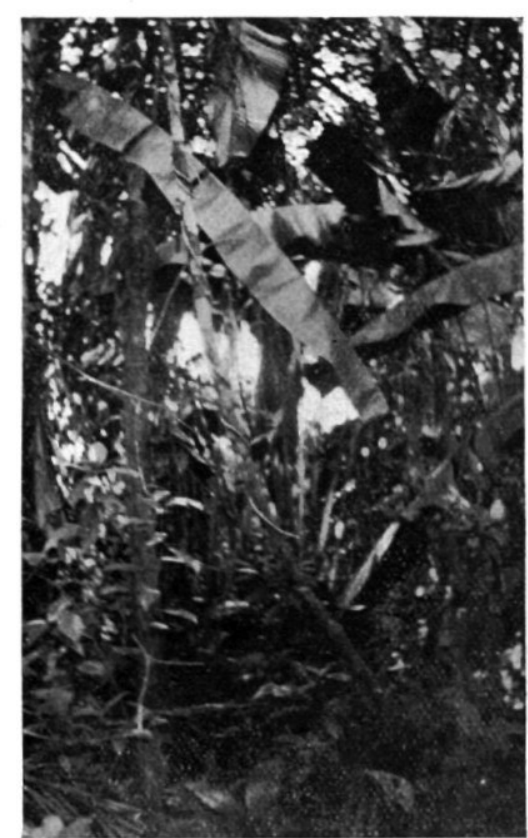

12. The "melki-tetei" as it grows in the woods
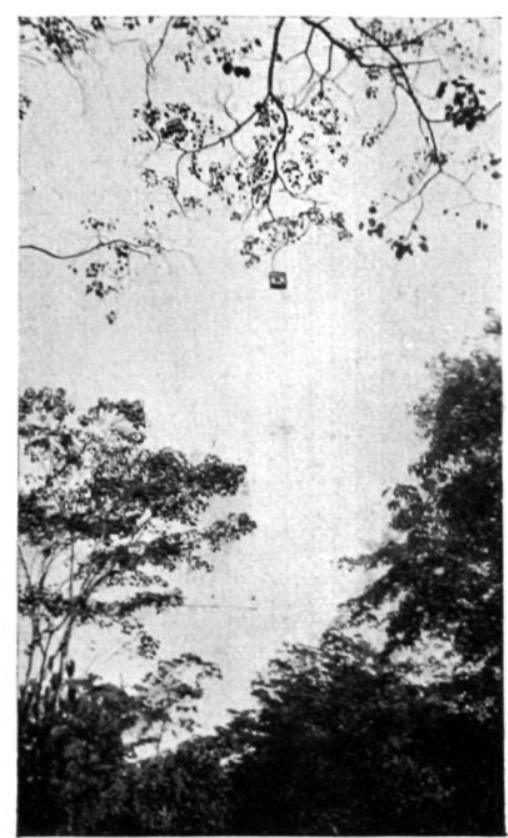

14. Trap-cage in position 
The hunt for young birds takes place in the beginning of the year, when most species breed. In January some parrots begin to clean out the old nest holes and lay their eggs which are hatched in February. Others begin in February and hatch in March or April. In May the hunt is practically over.

\section{THE EUPHONIAS}

The art of birdcatching has reached its greatest development in connection with the trapping of Euphonias. These pretty little tanagers, known as "canaries" in Dutch Guiana, are excellent songsters, and for that reason very much in demand.

The species caught in Surinam are:

Tanagra violacea violacea (Linn.). Violet Euphonia. "Geeldas" (Yellowthroat).

Tanagra finschi (Sclater and Salvin). Finsch's Euphonia. "Blauwdas" (Bluethroat).

Tanagra minuta minuta (Cabanis). White-vented Euphonia. "Parwa Blauwdas" (Parwa Bluethroat), or "Wittere" (White-tail).

Tanagra cayennensis cayennensis Gmelin. Cayenne Euphonia. "Grenadier" or "grangrandier" (a corruption of "grenadier").

Tanagra aureata intermedia (Chubb). Black-necked Euphonia. "Blauwhede Kanari" (Blue-headed Canary).

The adult male is known as "repman" (ripe man), the female as "oema" (woman, i. e. female), and the young male as "jongman" (young man). Young males in mottled plumage are known as "tigriman" (tiger man), and bright yellowish females as "kopro oema" (copper female).

The so-called "Wit-ai" (White-eye) is not a different species, but a bird whose eyes are infested by small whitish parasites which are easily removed by careful washing.

The Violet Euphonia, or Yellowthroat, is the most abundant of the Euphonias near the city of Paramaribo. It is 
encountered almost everywhere in the forests and woodlands, singly, in pairs, or in small flocks. When the socalled "kanari-zaad" (canary seed) on which they feed is ripe, they may be found in great numbers in the "seed trees", and are then easily caught.

The song of the Yellowthroat is very pleasing and consists of a variety of notes and phrases, some of which are said to be imitations of the calls of other species. We distinguish the following units: cheween, pee-ay, che-che-che, churr, towhee, kacheen kacheen, pin-pin, peen-peen. We have listened to a cage bird singing continuously for twenty minutes without a break. The call is a rapid cheween or peel-o-wheet. The "White-eye" seems to have more "kari-stem" (call notes) than ordinary individuals, and for that reason is highly prized by connoisseurs.

In captivity the Yellowthroat, if properly cared for, will live about five years. It is fed almost wholly on ripe plantains. Sometimes the varieties of banana, locally known as "Appra bakoeba" (Apple banana), "Baana bakoeba" (Plantain banana), and "Iengi bakoeba" (Indian banana), are also given, but the small varieties known as "Pikien misi fienga" (Little lady's finger) and "Soekroe bakoeba" (Sugar banana), are never used. Occasionally a little pepper or finely ground cinnamon is put on the food to make the bird call better. Ingredients of this sort are known as "dressi" (medicine). If the Euphonia is to be used as a decoy it is never given any water, because in that event the bird will sing more and call less, and it is the call rather than the song that is desired. When a male, attracted by the song, comes to the cage he is generally prepared to fight and is not interested in the food.

Finsch's Euphonia, or Bluethroat, is also abundant in the vicinity of Paramaribo. Smaller and more delicate than the Yellowthroat, its song, is also shorter and more refined. It has been rendered by the Negro-English words, tsjen-tsjen-tsjen, basi fisi tjari pori fisi kon agen, (Chenchen-chen, boss fisherman carried spoiled fish kom again). In English syllables it may be expressed as chen-chen- 
chen, bahsee feesee chahree pohree feesee kon again. The call is a prolonged peeng-peeng. Its war cry is a prolonged pee-ay, repeated several times, and is very effective in drawing the Bluethroats from far and near. For months a cage bird may not sound this cry, when suddenly, at the sight of another male of its own kind, or even a small brightly colored bird of an entirely different species, it will burst into a triumphant pee-ay. Towards sunset its peeng peeng grows softer and softer, until at last, as darkness falls, it fades away into an almost inaudible cheering.

The Bluethroat lives fairly long in the cage and is in much demand. Its food in captivity is the same as that of the Yellowthroat.

White-vented Euphonias are not so common near the city as the ordinary Bluethroat, but are found abundantly in the Parwa trees (Avicennia sp.) along the rivers. The song of this Euphonia is somewhat similar to that of the Bluethroat. Its call is a soft che-che-chewee or che-che-cheween-peeay, and its alarm note cheh-cheh-cheh. After repeating peet peet a while the bird suddenly bursts into a short song which may be rendered as keh-pee-pee-cheellwheet. The cry pee-ay is used more frequently by this species than by the common Bluethroat. The White-vented Euphonia does not live long in captivity, and for that reason is not much sought.

The Cayenne Euphonia, or Grenadier, is of rare and irregular occurrence near the city, but not uncommon in the Para district. It is highly prized as a cage bird, not so much for its song, however, as for its comparative rarity. Its song and call notes are both of coarser quality than those of the Yellowthroat. The Grenadier is pugnaceous and responds to the calls of the other Euphonias. It is seldom used as a decoy.

The Black-necked Euphonia is at times seen in numbers in the suburbs west of Paramaribo, generally during the Big Dry Season; but this species is not much sought by the birdcatchers, because it does not live long in captivity. 
Euphonias may be caught at any time of the year, but especially during the Big Dry Season. Early morning and forenoon are the best. In the middle of the day when it is hot the birds are not very active, and hence few trappers carry their operations into the afternoon.

The Euphonia catcher usually hangs his cage near a road. A foot bridge at Kokonassi, called "Pikien broki" (Little bridge), was at one time popular, and at present one at Krepi enjoys a good reputation. In the deep woods the chances of success are not so good, but in the second growth knownas "kapoeweri" they are excellent. Opinions differ as to the best sites, but it is generally agreed that the foliage must not be too thick. For that reason the "Boesi Papaja" (Cecropia sp.) is a favorite. It is best to suspend the cage from an outer branch rather than from one in the interior of the tree, but it should not be hung in the hot sun. The Bluethroats seem to have a particular liking for the Parwa (Avicennia sp.) and the "Koffimama" (Erythrina sp.). The food trees of the Euphonias offer unusual opportunities. Sometimes the berries are borne by the vines which grow upon the trees. Certain of these plants are known as "Geeldas-zaad" (Yellowthroat seed) and others as "Blauwdas zaad" (Bluethroat seed). Both the Yellowthroat and the Bluethroat are said to feed upon the berries of the Cedar.

The Bluethroat, White-tail, and Grenadier prefer the higher locations, but the Yellowthroat is not so timid and will come down into low trees and bushes. Notwithstanding these seeming preferences, Euphonias may be caught almost anywhere, and frequently they have been captured in the city in cages hung out of a window. It is not unusual for an escaped bird to come to an empty cage and permit itself to be caught soon after having gained its freedom.

Having selected the site, the trapper ties a stone to the end of a long, strong line and throws or rather slings it over the branch, lowering the weight to the ground. By skillful manipulation the weight is made to swing while being lowered so as to clear the bushes and other obsta- 
cles that may be in the way. If birdlime is to be used, he attaches the "tara-tiki" to the cage, sets his traps, adjusts the bait, and pulls the cage up into position. As an additional temptation he threads a piece of plantain on one of the sticks. If a branch of "seeds" is to be used, he hoists it in a similar manner ten to twenty feet from the cage. The catcher must stand by to remove his catch as soon as possible from the birdlime, but if a decoy and bait only are used he may leave the trap for some time. In so doing, however, he runs the risk of having the cage destroyed by hawks or other large birds. If he remains on the scene he need not take the precaution to conceal himself.

The decoy is called a "set-kanari". A bird intended for that purpose should always be kept outdoors so that it may become accustomed to the surroundings. The best birds are the adult males, although the females are also used. If the decoy is a good one it will begin calling at once, even while being hoisted; but if for some reason or other it remains silent, the trapper is able to stir it to action by imitating the Euphonia calls.

Suddenly a faint peel-o-wheet is heard, hardly discernible to the untrained ear, but the boys and the decoy have caught the sound, and the excitement begins in earnest. Instantly the decoy aswers with a short pin-pin-pin, to which the wild bird, still far off, responds with a ringing peel-o-wheet. Louder and louder comes its repeated cheh, cheh, cheh, and finally a silvery peen peen. Now, unable to restrain itself any longer, the decoy bursts into a prolonged peeng, peeng, known as the "tapoe stem" (closing or stop note), which is music to the trapper's ear, for after that the Euphonia is considered as good as caught.

On arriving the wild bird flies around the cage as if investigating and finally goes to the trap or the birdlime. When a bird hovers over the birdlime as if in doubt whether to alight, it is said that "a poko gi a tara" (it balances, i.e. hovers for the tar). After alighting it will try to free itself, flutter a few seconds, fall over, and hang head down. In this condition it will rarely struggle any more, but will hang calmly as if awaiting developments. Some- 
times a number of birds come and several may be caught at one time. Birds approaching with wings dragging are particularly desirable.

The captured Euphonias are placed for safe keeping in a stock cage and covered with a cloth which apparently has a soothing effect on the wild birds. Birdcatchers usually cover their cages in this manner while on their way to and from the hunting grounds. Much interest is displayed in the new captives. Those which appear tame from the start will be the best cage birds.

An account of Euphonia catching in Surinam would not be complete without a few words about the contests in which the boys engage. These contests take different forms depending upon the whims of the promoters. In one form the birds matched against each other are placed in adjoining rooms so that they can hear but not see one another. A record is kept of the calls, omitting the peet peet uttered in jumping from perch to perch. The bird that calls, or else sings, the most wins. In another form of contest the Euphonias are placed in sight of each other with cages touching. A good bird will drag its wings and begin calling at once, otherwise it will begin a soft, almost inaudible chipping. A good caller is known as a "karikanari" (calling Euphonia). If the match is for "fon-teki" (win-take), the loser must pay. If it is for "set-kanarigo" (decoy go), the winner takes the decoy, but if not so agreed at the outset, he receives a "pai-kanari" (pay Euphonia), usually a female or a less desirable male. The boys take great pride in their pets and frequently give them high-sounding names such as "Napoleon", or "Spartan". Any one who is repeatedly successful in these contests and who is in other ways an expert in these matters is known as a "kanari-baas" (Euphonia-boss) or "kanaritata" (Euphonia-father).

THE FINCHES

The practice of keeping native finches was introduced from Demerara at a comparatively recent date. Forty years ago these songsters were practically unknown as 
cage birds in Surinam, but now they are quite the fashion. First and foremost are the Twatwa, Oryzoborus crassirostris crassirostris (Gmelin), also known as "Bigi-mofo Aleisifowroe" (Big-mouthed Ricebird), and the "Geelbek" (Yellowbill), Sporophila schistacea arthuri Penard.

Other species for which there is more or less demand are:

Oryzoborus angolensis brevirostris Berlepsch. Twatwa Slave. "Redi-borstoe Blakka Aleisi-fowroe" (Red-breasted Black Rice-bird).

Sporophila castaneiventris Cabanis. Chestnut-bellied Seed-eater. "Reddi-borstoe Aleisi-fowroe" (Red-breasted Rice-bird).

Sporophila minuta minuta (Linn.). Pigmy Seed-eater. "Aleisi-fowroe" (Rice-bird).

Sporophila americana (Gmelin). White-throated Seedeater. "Jack".

Sporophila lineola lineola (Linn.). Moustache Seedeater. "Jack", or "Blakka-nanga-witti Aleisi-fowroe" (Black and white Rice-bird).

Volatinia jacarini jacarini (Linn.). Jacarini Grassquit. "Srio" (in imitation of its note).

The Twatwa is by far the best songster. Its song varies, but may be expressed roughly as cheep cheep cheepee cheeah cheeah chopee cheeah cheeah. The Twatwa seems to be at its best when the wind blows and the leaves rustle. The bird must be quite tame before it will sing good in captivity. Its call note is chee, or $t s h o k$, or a sound like a kiss. From the call it passes to the song with a sharp note or a short tee tee chewee.

Twatwas frequent fields, weedy pastures, and clearings, especially near the edges where they can take to the thickets. They are very shy and keep away from habitations. For that reason they are rare in the suburbs of Paramaribo, but at Liforno, in the Beneden Para district, they are common. In the Little Dry Season they appear to be more distributed than at other times.

The best time to catch Twatwas, and for that matter 
the other finches also, is in the early morning up to about ten o'clock. The bait used in the trap-cage is rice or ordinary canary seed. Seeds of native grasses on which the Twatwa naturally feeds are also used, particularly the socalled "Mangrassi", Eleusine indica Gartn. But whatever the bait may be, it is best to set the cage near the natural food.

As in Euphonia catching the practice of trapping seedeaters varies considerably depending upon the experience and judgement of the individual. In general the cage must not be placed in or under bushes or trees, but near the edge of a clearing about ten feet or so away from the nearest bush or seed plant. The site having been selected the trap cage is hung on a pole with a nail or the stub of a branch near the top. This is known as a "trot-tiki" (trotstick), and the manner of hanging as "trot".

Generally birdlime is employed. The treated sticks are attached to the cage as in Euphonia catching, but more frequently the "valsch tara" method is used, in which case they are placed a few feet away.

Occasionally the birdlime is applied directly to a seedbearing stalk after thinning out the plants in the immediate vicinity.

The decoy may be of either sex. A young male is better than a female, but the black adult male, known as a "kak' (cock), is by far the best. The tame bird will begin to call soon after being left alone. Its efforts may be rewarded by an answering call, but generally they are not. While the decoy is calling tsok tsok, the wild bird is approaching stealthily, creeping on the ground or silently working its way through the thickets, weeds, or long grass. If at such a time the tame bird should break into song the approaching Twatwa may lose all caution and appear suddenly on the scene. Sometimes the birds will sing alternately, but when they are in sight of each other both become silent. If both should happen to sing at the same time, the wild bird seems to lose its self-control and comes dragging and beating its wings. It will fly around and around the cage, and perhaps be caught then and there. If not it 
will sooner or later fly to the food plants and eventually to a stalk covered with birdlime or to a pole with the treated perches.

If the male of a mated pair has been captured the birdcatcher should not attempt to catch the female, for it is said that the latter will soon mate again, thus presenting another golden opportunity. Occasionally a wise old bird defies capture by ordinary methods, stirring the trapper to exercise his ingenuity to the utmost. Three Twatwas is considered a good catch for the day.

Most Twatwas are very wild when first caught. In fact some can never be tamed and will kill themselves striking the wires of the cage. For this reason the Twatwa catcher, before selling a bird, keeps it long enough to determine whether it is a good one or not. It may also be that what at first appears to be a female, is in reality a young male, for as a rule the males are more often victims than the females. Cage birds may live as long as fifteen years.

The Gray Seed-eater or "Geelbek" of Surinam is at present an exceedingly popular cage bird. It has a pleasing song, although some of the notes are rather squeaky and insectlike, especially when heard in the house. The performance may last a minute or even longer. Expressed in syllables it is approximately: pe che che te swee swee swee chee-o chee-o pe che chee-e-ke, followed by a jumble of rapid twitters slowing down towards the finish, after which the song may be repeated with variations. A shorter song consists of the syllables che swee swee swee swee cheh cheh, or simply che swee swee swee swee. The call note is a sharp tseep or tsip, or chepee; The alarm note is a lower tsup.

This species is a stranger in the thickly settled parts of the city, although it is occasionally seen in the gardens. At Tourtonne and in back of the Cultuurtuin they are more frequently seen. Near the Eerste Rijweg they seem to be of irregular occurence, and appear from time to time in small flocks. At Lelydorp, however, where the Javanese have patches of rice under cultivation they are common. 
Gray Seed-eaters are easier to catch than Twatwas and are captured by the same general methods. Whether a trap-cage only is used or "valsch tara", a decoy is necessary if the rice has not yet formed. The cage is hung on a "trot stick" as in Twatwa catching, and perches treated with birdlime are attached to it and to poles not far away. A few grains of rice are sometimes inbedded in the birdlime. Passing birds attracted by the calls of the decoy, settle down on the neighboring trees and eventually fly to the cage.

When the rice is ripening the seed-eaters need no invitation and the decoy can be dispensed with. In that case the best fields in which to carry on operations are those in which a few small trees are standing. The latter are usually covered with epiphytes whose aërial roots, hanging down to the rice tops, are known as "jaga-jaga". The most common of these is called "njamsi-makka", and its roots "njamsi-makka-tetei". About fifteen feet from the tree selected the birdcatcher plants a pole to which are attached the perches with birdlime.

Prepared for a feast the little Gray Seed-eaters come in small flocks to the trees in the rice field. Down the "jagajaga" they work their way, one by one slipping off into the rice. Some may go directly to the birdlime, but whether they do so at once or not, sooner or later one of them is sure to come out to reconnoitre, or in quarreling chase another to the perch. When a bird gets caught it should not be removed immediately, because its cries will draw others to the scene, and perhaps several may be captured. Immature birds appear to be more easily deceived than adults. Sometimes the birdcatcher hides nearby, and when the birds are quietly feeding shows himself suddenly. The frightened birds fly to the perches, and in that manner many may be caught.

Other seed-eaters, including the Twatwa Slave, Whitethroated Seed-eater, Moustache Seed-eater, Jacarini Grassquit, Chestnut-bellied Seed-eater, and Pigmy Seedeater are all caught by similar methods, but as the de- 
mand for these is much less than for the Twatwa and the Geelbek no special effort is made to trap them.

MACAWS, PARROTS, AND PAROQUETS

All members of the family Psittacidae are sought. Young macaws and parrots are taken from the nest holes and paroquets are caught with birdlime. Macaws taken as nestlings are almost unknown in Surinam, most individuals in captivity having been wing-shot. They are easily tamed and live long.

The Blue and Yellow Macaw, or "Tjamba Rafroe" (Tjamba "Raven"), Ara ararauna (Linn.), nests in hollow trees in the high woods of the interior and also in the coast region, but the Red and Blue Macaw, or "Bok", Ara macao (Linn.), and the much rarer Green and Red. Macaw or "Warau Rafroe" (Warau "Raven"), Ara chloroptera Gray, all breed, so far as we know, in the interior only. The Brown-chinned Macaw, or "Rafroe Prakiki" (Macaw Paroquet) Ara severa severa (Linn.), often associate with the Amazon Parrots, breeding near the coast at the same time and in the same localities, in the beginning of the year. Young ones of this species are frequently offered for sale with young Amazons. Hunters say that Brownchinned Macaws, after having been robbed of their young, never use the same nest hole again.

The most common parrot is the Amazon, or "Groen Popogai" (Green Parrot), Amazona amazonica amazonica (Linn.). It breeds in hollow trees along the coast, beginning in January. In April the hunt for young parrots is at its height. Those taken from the nest learn to talk more readily than wing-shot individuals. They live to a good old age. Amazons prefer to nest in tall trees, but sometimes the site is so low that the young can be reached without any trouble. If the nest hole is not too high and the tree sufficiently decayed, the hunter makes a hole in the trunk and pokes into it with a stick until he reaches the nest.

The following species of parrots also are taken: 
Amazona aestiva aestiva (Linn.). Blue-fronted Parrot. "Mazon Popogai" ("Amazon" Parrot).

Amazona farinosa farinosa (Boddaert), Mealy Parrot. "Redi-flei Groen Popogai" (Red-winged Green Parrot).

"Amazona festiva festiva (Linn.). Red-rumped Parrot. "Redi-bakka Popogai” (Red-backed Parrot).

Pionus menstuus menstruus (Linn.). Blue-headed Parrot. "Margerietje" (Marguerite).

Pionus fuscus (Muller). Dusky Parrot. "Basra Frans madam" (Bastard French madam).

Deroptyus accipitrinus accipitrinus (Linn.). Sun Parrot. "Fransmadam" (French madam).

Urochroma purpurata (Gmelin). Purple Parrot. "Blauwbakka Prakiki"' (Blue-backed Paroquet).

There is no particular season for catching paroquets, but the beginning of the Dry Season is considered the best time of the year.

The species commonly caught are:

Eupsittula pertinax chrysophrys (Swainson). Guiana Brown-throated Paroquet. "Karoe Prakiki" (Corn Paroquet).

Psittacula passerina passerina (Linn.). Emerald-rumped Love-bird. "Okro Prakiki" (Okra Paroquet).

Brotogerys chrysopterus (Linn.). Golden-winged Paroquet. "Geel-ai Prakiki" (Yellow-eyed Paroquet).

Less frequently the following:

Pyrrhura picta picta (Müller). Scaly-breasted Paroquet. "Pinni Karoe Prakiki" (Variegated Corn Paroquet).

Urochroma bataviaca (Boddaert). Black-winged Paroquet. "Pinni Prakiki" (Variegated Paroquet).

Pionites melanocephala melanocephala (Linn.). Blackheaded Paroquet. "Wit-bere Prakiki" (White-bellied Paroquet), or "Morisi Margerietje” (Eta Marguerite).

The Emerald-rumped Love-bird is always "set" in a cage "trotted" on a pole, with birdlime perches fastened 
to the cage or directly above it. Another pole equipped with similar perches may be planted about ten feet away. They must not be too high, however, otherwise the captured birds cannot be reached, and some may escape. The poles are always placed at the side of a road or in a field or clearing in proximity to but not too near trees or shrubs which would offer convenient resting places. Sometimes a birdcatcher strips a small tree of all its leaves except at the tips of the branches and treats all the branches with birdlime.

Only one decoy is used. If two are "set" together they will not call. The cry is cree cree cree. So long as the wild paroquets are flying about the tame bird will call, but as soon as they alight it becomes silent and remains so until the flock flies again. Usually one bolder than the rest will come to the cage. Love-birds may be caught in great numbers by this method.

As a rule the Brown-throated Paroquet is not "set" in a cage, but is placed upon a perch without birdlime. Tame birds with trimmed wings will seldom attempt to escape.

POPULAR BELIEFS

We add a few scraps of folklore pertaining to the subject of birdcatching:

1. If a cage should fall, and the bird it contains appear dazed, the cage with its contents must be rapidly twirled. This action is supposed to restore the bird to its senses.

2. A bird that has been stunned can be revived by blowing gently under its tail.

3. To revive a bird that has been stunned force some saliva into its mouth.

4. It is considered unlucky to sell a bird that has just been caught.

5. The best method of trimming a bird's wings is to bite off the wing feathers, or else to pull them out. Scissors must not be used.

6. To remove birdlime from a bird's foot use your teeth. 
7. In the excitement of watching a bird near the trap it is considered proper to assume some grotesque posture and maintain it until the bird either is caught or flies away. It is then that the expression "horbakka" (hold back) is used as a warning not to move.

Arlington, Mass., U.S.A. 